\title{
An experimental study on a granular-ice storage method
}

\section{グラニュラー・アイス方式水蓄熱に関する実験的研究}

\author{
Fujio SUDA, Miyoko TOYOZAKI and Chieko MORISAWA \\ Department of Resources and Environment Science, School of Humanities and Culture, \\ Tokai University, 1117 Kitakaname, Hiratsuka, Kanagawa 259-12 JAPAN \\ TEL:81-463-58-1211(EX.3417) FAX:81-463-50-2208 \\ ( Received 16, November 1995 Accepted 19, February 1996)
}

\begin{abstract}
Ice-storage system for air-conditioning by utilizing off-peak night time power service provides a good way of energy saving. In the present study, a new type ice-storage system has been proposed, which contains granular-ice crystals of some millimeter in diameter. This syatem has several advantages ; for example, high ice-making efficiency, high responsibility and simplicity. Fundamental experiments were carried out to seek conditions to produce granular-ice crystals successively; They were formed through injecting water droplets into a low temperature immiscible coolant with the specific gravity smaller than water. Their formation processes were observed in a small transparent ice-storage tank of $50 \mathrm{~cm}$ depth. As an immiscible coolant, kerosene has been utilized. Smooth granular-ices with uniform dimension were produced successively at the set-temperature lower than $-20^{\circ} \mathrm{C}$. Discussions have been made on the improvement of this method for practical application.
\end{abstract}

Key words; Ice-Storage System, Granular Ice, Energy Saving, Low Temperature Immiscible Coolant.

\section{INTRODUCTION}

日本における発電用エネルギーの全一次エネルギー に占める割合は増加の一途をたどり、1992年には遂に 40\%にまで達した。同時に、電力需要の季節間、平休日 間、昼夜間格差も広がりつつある。特に夏期における 昼夜間格差は大きく、昼間の電力需要は深夜の2倍以上 にもなる。それはひとえに日中の冷房需要の増加によ るものである。

電力需要の格差を平準化して、負荷率を上げること は新たな電源設備の設置と等価、もしくは自然環境に 対する負荷を考慮するならば、それ以上の価值があ る。平準化のためには、需要がピークとなる時間帯の 電力を需要の少ない時間帯の電力で賄うように時間帯 をずらせばよい。揚水発電はひとつの方法であるが、 どこでも可能という訳ではない。夏期日中時のピーク 負荷回避の為に、現在最も注目されているのが水蓄熱 システムである。これは格安な夜間電力を利用して製 氷を行い、昼間冷房用として利用するシステムであ る。

氷蓄熱法は、水の凝固潜熱を利用するため、水蓄熱 法に比べ5～8倍の蓄熱密度を持ち、大きな電力シフト が期待できると共に、蓄熱槽容量を大幅に低減できる という利点がある。しかし、一方では製氷時における
冷凍機成績係数(COP)の低下、生成する氷の物理的性状 (伝熱特性、体積膨張など)がやっかいな問題となり、シ ステム構築の上で制約が多くなりがちである。1これら の問題点を克服するために、多種多様な水蓄熱法がこ れまでに提案されてきた。

永蓄熱システムを生成・使用する氷の性状によって 分類すれば、2スタティック型とダイナミック型に分け ることができる。スタティック型では、氷は基本的に は伝熱面上に生成される。そのため生成される水自体 が熱抵抗体となり、製水熱交換器の伝熱管間隔(設計水 厚み)によっては、冷凍システムの運転効率を低下させ ることがある。また、蓄熱槽内に熱交換器を設置する 必要がある。一方、ダイナミック型では、蓄熱槽と氷 生成部は分離しており、その分設計上の自由度は確保 される。また、生成される氷はリキッド・アイス状や シャーベット状であり、システムの取り扱いが複雑に なるものの水厚を大きく取らずに製水・解水するため COPの低下を防ぐことが期待されている。

渡辺らは最近、フラジル・アイス方式のダイナミッ ク型水蓄熱システムを提案している。3-5この方式は水 中に $0^{\circ} \mathrm{C}$ 以下に冷却した非水溶性の液体を散布して、 シャーベット状の水を生成する方法である。この方式 
では、液-液直接接触熱交換による製水をするため、製 水時の熱交換効率が良い。このとき使用される非水溶 性液体の比重は1.8程度であり、ポンプで循環利用され る。その成分の詳細は明らかにされていないが、実験 ではフッ化炭素(パーフルオロカーボンPFC、基本分子 式: $\left.\mathrm{C}_{8} \mathrm{~F}_{18}\right)$ を用いている。

われわれが本研究で提案する氷蓄熱法は、渡辺らの 方法と同様、液-液直接接触熱交換を利用するものであ るが、逆の発想により、比重が1より小さい低温の不凍 液中に水を滴下することにより、粒状水(グラニュラー ・アイス)を生成しようとするものである。われわれは 以下ではこれを「グラニュラー・アイス方式」の水蓄 熱法と呼ぶことにする。この新方式の利点としては(1) 直接接触による熱交換であるため水の生成効率が良 い、(2)滴下する氷の大きさをコントロールすることに より、冷熱取り出しの際の応答性と持続性を最適化で きる、(3)冷熱取り出しを熱交換器で間接的に行うこと も、直接流して利用することも可能である、(4)装置は 極めて単純であり特別な制御を必要としない、などが 考えられる。

本研究はダイナミック型水蓄熱法のひとつとして、 「グラニュラー・アイス方式」を提案し、グラニュ ラー・アイス生成に関する基礎的な実験を行った結果 である。

\section{EXPERIMENTAL APPARATUS AND METHOD}

グラニュラー・アイス生成に要求されるクーラント の条件としては、(1)水に不溶で、(2)比重が1より小さ く、かつ(3)利用温度範囲において不凍性であることな

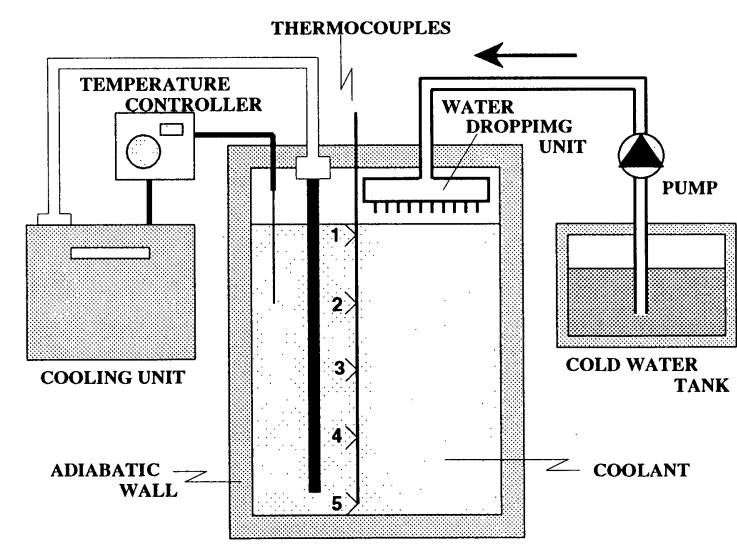

(a)

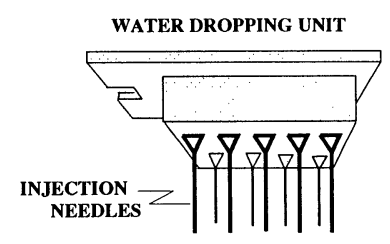

(b)

FIG. 1 Schematic diagram of the experimental setup (a) and the water dropping unit (b).
どが最低限要求される。さらに、(4)安全性、(5)経済 性、(6)性質の経時変化が少ないことなどもつけ加えら れるであろう。これらすべての条件に必ずしも合致す るものではないが、ひとつの試みとして、石油系の溶 液を利用することにした。

グラニュラー・アイス生成実験に入る前に、これら のクーラントにより目的とするグラニュラー・アイス がうまく生成されるか確かめるための予備的な実験を 行った。クーラントとしてエンジン・オイルを用い、 これを深さ約 $15 \mathrm{~cm}$ のジュワー瓶に入れて冷却し、これ を擋汼して一様温度にした後、あらかじめ4～5ㄷに冷 却した水を注射器で滴下し、生成された氷を観察し た。粒径は注射針の太さにより変わり、1～5 $\mathrm{mm}$ 範 囲でコントロールできた。灯油の場合にも同様な実験 を行った結果、低粘性のため底に到達するまでの時間 が短い分、温度をさらに下げる必要があった。

これらの結果を踏まえて、Fig.1(a)に示すような装置 を組立て、グラニュラー・アイス生成実験を行った。 この装置はクーラントの入った蓄熱槽(図の中央部)、 冷却ユニット、冷水タンクとポンプにつながる冷水滴 下ユニット、それに温度測定用の熱電対とレコーダー からなる。

蓄熱槽は $5 \mathrm{~mm}$ 厚の透明アクリル板製で、高さ50 $\mathrm{cm}$ 、横 $14 \mathrm{~cm}$ 、奥行き $4 \mathrm{~cm}$ (内容量 2.8 リットル)である。 周囲を50 mm厚の発泡ウレタンで断熱した。断熱壁に は、内部観察のためのいくつかの蓋付きの穴が設けて ある。クーラントを冷却するためのクーリング・ユ ニットには、直膨式投げ込みクーラー(YAMATO、 NEOCOOL DIP BE200F、定格電力115W)を温度調節器 と共に設置した。槽内温度測定のため、0.1mm $\phi \mathrm{K}$ タイ プ熱電対5組を槽上端からそれぞれ12、21、30、39、48 $\mathrm{cm}$ 位置に取りつけた。各温度は打点式レコーダーに 記録される。

蓄熱槽上部には、水を滴下するための滴下ユニット が取り付けてある。Fig. 1(b)にヘッド部分の模式図を示 す。これはアクリル板製の箱に注射針を複数本取り付 けたものである。種々のヘッドを作製したが、次節に 示した結果は内径 $0.7 \mathrm{~mm}$ の注射針15本のヘッドを使っ て得られたものである。このへッドに冷水タンクから ポンプ(YAMATO、MASTER FLEX MODEL 7018-20)て 2〜 $3^{\circ} \mathrm{C}$ 冷水を供給、滴下した。滴下量は一分あたり 約 $20 \mathrm{~cm}^{3}$ (直径 $3 \mathrm{~mm}$ の水滴にして約 1500 個)である。

製水の方法、および手順は以下の通りである: 蓄熱

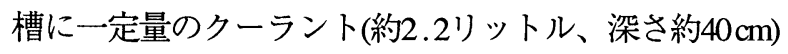
を入れ、冷却温度を設定し、冷却開始。一定の幅で温 度変動を繰り返すようになったら、底部をマグネ ティック・スターラーで数分間弱く摚䢁する。その 後、ポンプを始動、冷水を滴下する。そして、氷ので きる様子を観察。また、できた氷を素早く取り出し、 冷蔵庫に移し、観察、および写真撮影を行った。 


\section{RESULTS AND DISCUSSION}

以下に示す結果はすべて、ターラントとして灯油を 用いた場合である。Figure 2 に、設定温度-20员の場合 の蓄熱槽内各部の温度变動の測定結果例を示す。

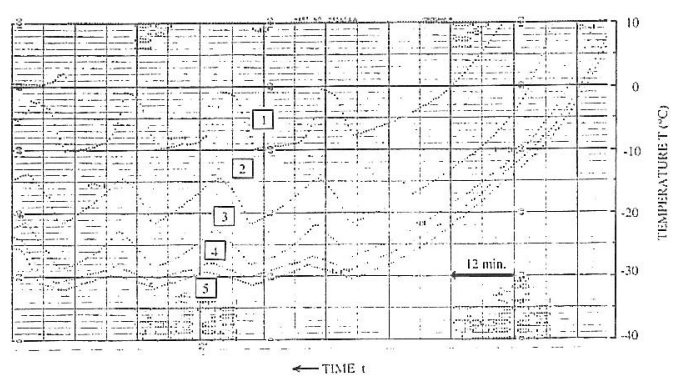

FIG. 2 An example of temperature variation measured at the set-temperature of $-20^{\circ} \mathrm{C}$

図中の番号1～5は熱電対の位置を表している(Fig.1(a) 参照)。冷却開始約50分後より、温度調節器が働き一定 温度を中心とした周期的温度变動を繰り返すようにな る。温度調節器のセンサーは2番の熱電対近くに設置 してある。Figur 3にこの場合の深さ方向の温度分布を プロットした。各プロット点に付けた横棒は、その点 の温度振動の幅を示している。にれはマグネティック ・スターラーで擋挥を行う前の温度分布であるが、弱 い擋汼により底部は数度 ${ }^{\circ} \mathrm{C}$ 上昇し、上部は逆に数度 ${ }^{\circ} \mathrm{C}$ 低下する。)

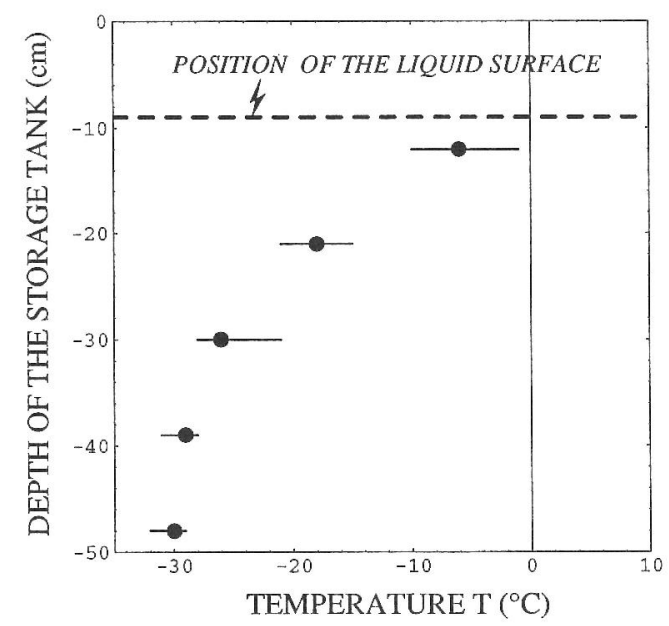

FIG.3 An example of temperature distribution in the storage tank measured at the set temperature of $-20^{\circ} \mathrm{C}$.

Photo 1 に2、3の設定温度に扔ける蓄熱槽底部での 製水過程の様子を示す。(a)、(b)、(c)の設定温度はそれ ぞれ-5、-10、-20ㄷである。(a)の場合には、グラニュ ラー・アイスにはなっておらず氷䊀は互いに融合し、 上方に向かってもやもやした形を作りながら成長して いる。(b)の場合には、よく見ると一個一個は粒状を呈 しているが、それらは部分的に融合しあい、やはり上
方に向かってもやもやした雲形を形成しつつ伸びてい る。一個一個の水が独立した球状になるのは、設定温 度が-20다になってからである。それが(c)の場合で あり、氷の粒は積み重なりつつ山を形成する。
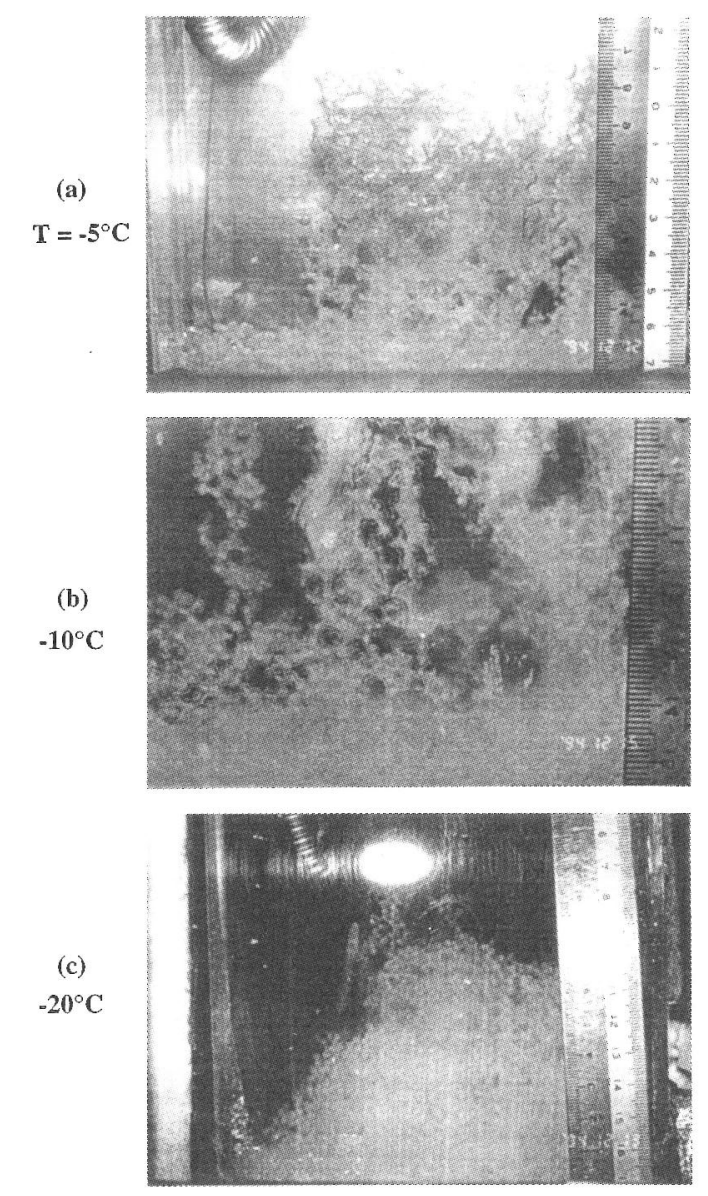

Photol Photographs of growing ice crystals on the base of the storage tank. (a) $-5^{\circ} \mathrm{C}$ (b) $-10^{\circ} \mathrm{C}$ and (c) $-20^{\circ} \mathrm{C}$.

蓄熱槽から取り出した直後のグラニュラー・アイス の写真をPhoto 2に示す。(a)、(b)、(c) の設定温度はそ扎ぞ れ-15、-20、-250で゙ある。(c)のグラニュラー・アイス が青っぽく光って見えるのは、観察し易くするため滴 下する前の水にブルーのインクを混入したためであ る。インクを混入していない場合についても実験した が、混入による影響はほとんど見られなかった。(a)の 場合には、写真左側に見られるように、柱状に成長し た氷も観察される。しかし、-20、-250では、ほとんど が直径 $3 \mathrm{~mm}$ 程度のグラニラー・アイスになっている。 低温ほどサラサラした感じになる。

このように、クーラントとして灯油を用いた場合、 設定温度を-20ํ以下しないと年ラニュラー・アイス は得られていない。それより上の温度では、少ラニュ ラー・アイスは互いに融合してしまったり、雲のよう にモヤモヤした形になる。

設定温度 $-20^{\circ} \mathrm{C}$ は実用上低過ぎる温度である(設定温 度の低下は製水時のCOPの低下を招く)。本実験装置の 

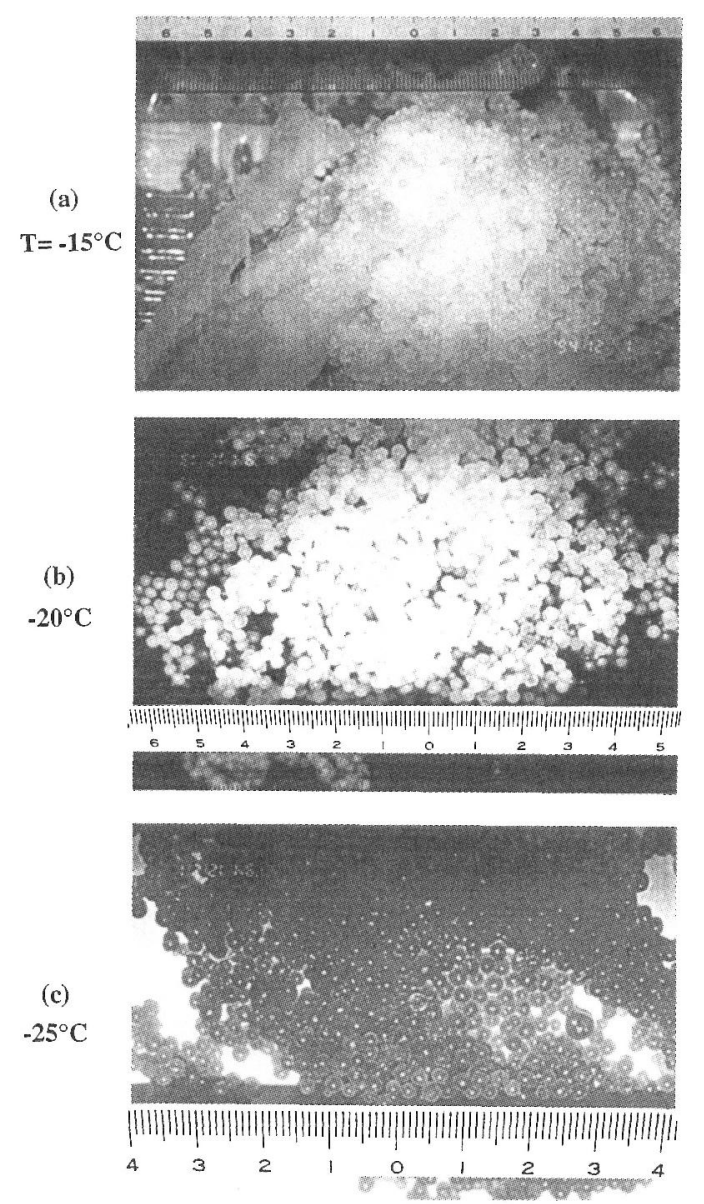

Photo 2 Photographs of granular-ice crystals produced at the set-temperature of $-15(\mathrm{a}),-20(\mathrm{~b})$ and $-25^{\circ} \mathrm{C}(\mathrm{c})$.

場合、水滴がクーラント中を落下し、液槽の底に達す るまでの落下距離はせいぜい $40 \mathrm{~cm}$ である。野間らはフ ラジル・アイス方式の場合について、比重1.80液滴が 液-液直接接触熱交換しつつ水中を落下して行く際の計 算から、周囲冷媒温度と液滴の初期温度差が $-5 \sim-10^{\circ} \mathrm{C}$ のとき、液滴が完全に熱交換を終えるに要する落下距 離は1〜1.5mであるとしている。6このことからも、わ れわれの $40 \mathrm{~cm}$ とう落下距離は短過ぎ、その分設定温 度を低くする必要があったものと推定される。さら に、本実験の場合滴下ユニットからの水滴の個数は 1
分間に約1500個であり、クーラント中の液滴の通路近 傍は液滴との熱交換のため、温度が上がり凝固しにく くなっていることも考えられる。

これらの問題点を打開してより高い設定温度でもグ ラニュラー・アイスが連続的に生成されるようにする ための方策として、次のようなことが考えられる:(1) 装置を大型化して落下距離を稼ぐ、(2)粘性のより高い クーラントを使うか、またはクーラントをポンプで盾 環させて上昇流を起こし、落下時間を稼ぐ、さらには (3) 凝固の核形成を促進寸る適当な物質を水中に混入 し、過冷却解消温度を高める、などが考えられる。現 在、これらのことを考慮に入れた循環型の試験装置を 作製し、実験中である。

\section{SUMMARY}

グラニュラー・アイス方式の水蓄熱システムの可能 性を探るため、グラニュラー・アイス連続生成実験を 行った。比重がより小さく、かつ非水溶性の低温不 凍液中に水を滴下することにより、粒状の水を連続的 に生成することができた。現状では、溶液温度が低過 ぎるため、製水時のCOPの低下を招く恐れがある。そ

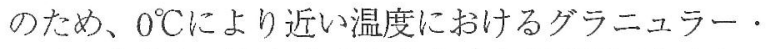
アイス生成を可能とするような亡夫が必要であるとの 結論に達した。

\section{REFERENCES}

${ }^{1}$ Itoh and Suzuki: Energy Storage System (Japan Society of Energy and Resources, 1992) p. 196.

${ }^{2}$ Shabamoto: Kuuki-chouwa Eiseikougaku, 64 [10] (1986).

${ }^{3}$ Watanabe, Noma and Hachimonji: Proc. of the 69th Meeting of Nippon Kikai Gakkai,B 485 (1992).

${ }^{4}$ Watanabe, Yamasita, Noma and Hachimonji: Proc. of the 30th National Heat Transfer Symposium of Japan, 1 415 (1993).

5Watanabe: Journal of the Heat Transfer of Japan, 34 [135] 73 (1995).

${ }^{6}$ Noma, Watanabe and Hachimonji: Proc. of the 69th Meeting of Nippon Kikai Gakkai, B 488 (1992).

'95 SAS Intelligent Symposium 